DOI : $10.14746 /$ rie.2014.8.31

\title{
Między polityka a rynkiem. Kryzys Unii Europejskiej w analizie ekonomistów i politologów, pod red. Tomasza Grzegorza Grossa, Uczelnia Lazarskiego, Warszawa 2013, ss. 242.
}

Kryzys gospodarczy ostatnich lat wstrząsnął gospodarkami wielu państw świata. Nie ominął także członków Unii Europejskiej. Znacznie spadły najważniejsze wskaźniki, przede wszystkim produkcja, tempo wzrostu PKB oraz poziom zatrudnienia. Kryzys należy rozpatrywać zarówno w zakresie gospodarki, jak i w ramach układu politycznego. Pojawiły się zaburzenia w zarządzaniu kryzysem oraz zwalczaniu problemów pojawiających się w instytucjach.

Tematyce kryzysu poświęcona jest publikacja Między politykq a rynkiem. Kryzys Unii Europejskiej w analizie ekonomistów i politologów wydana przez Uczelnię Łazarskiego. Autorzy pracy zbiorowej wyszli naprzeciw rysującej się potrzebie głębszego przeanalizowania związków zachodzących pomiędzy zjawiskami gospodarczymi i politycznymi podczas trwania kryzysu. Publikacja, przygotowana pod redakcją Tomasza Grzegorza Grossa, stanowi kompleksowe przedstawienie tych relacji.

Praca zawiera osiem artykułów dotyczących istotnych kwestii zjawiska kryzysu, pogrupowanych w dwie części tematyczne. W pierwszej znajdują się dwa artykuły, w drugiej sześć. Publikację poprzedza obszerne wprowadzenie Tomasza Grzegorza Grosse. Odpowiada w nim na pytanie czym jest kryzys. Porusza takie kwestie jak problem wzrostu, problem strukturalny, problemy sterowności i zarządzania oraz problem legitymizacji. Następnie przybliża płaszczyzny kryzysu w Europie (ekonomiczną oraz polityczną) zwracając jednocześnie uwagę na ich przyczyny. Omówione zostały również kwestie związane z układem geopolitycznym w kontekście stabilności reżimu monetarnego, jego legitymizacji oraz kryzysu centrum politycznego. Ostatnia część wprowadzenia stanowi analizę kryzysu w strefie euro jako czasu na dostosowanie ekonomiczne, strukturalne i legitymizacyjne. Podsumowując Gross stwierdza, że czas kryzysu wpłynął na wzmocnienie znaczenia instytucji międzyrządowych, a osłabienia modelu wspólnotowego. Wyraźniejsza stała się hierarchizacja władzy pomiędzy państwami członkowskimi, która uwidacznia się w instytucjach wspólnotowych. Zauważalne są skłonności do fragmentaryzacji Unii Europejskiej zarówno pod względem politycznym, jak i gospodarczym.

Pierwszą część zatytułowaną Analiza ekonomiczna rozpoczyna artykuł Jana Fałkowskiego Problem finansów publicznych w krajach UE z punktu widzenia nie tak odległej historii oraz kilku teorii nowej ekonomii politycznej. Omówiony w nim problem stanowi jedno z najistotniejszych wyzwań, przed którymi stanęły państwa członkowskie Unii Europejskiej. W artykule zbadano problem kryzysu, patrząc na niego z perspektywy ostatnich dziesięcioleci. Podjęto próbę wythumaczenia czynników stanowiących podłoże trudności związanych z zadłużeniem sektora finansów publicznych. Zaprezentowane zostały także teorie umożliwiające badanie długu publicznego poprzez uwzględnienie instytucji politycznych oraz wzajemne oddziaływanie pomiędzy instytucjami gospodarczymi i politycznymi. Autor dowodzi, że problemy z zadłużeniem sektora finansów publicznych nie są jedynie skutkiem kryzysu ostatnich lat, a są efektem wieloletniej tendencji.

Kolejnym jest artykuł Łukasza Hardta Kryzys zarzadzania gospodarczego w strefie euro - brak optymalnego obszaru politycznego i kryzys koncepcji dobrego zarzadzania? Przybliżona zostaje w nim panująca pomiędzy państwami członkowskimi nierównowaga gospodarcza oraz trudności w zarządzaniu.

W części drugiej pracy zbiorowej (Analiza politologiczna), obszerniejszej, znalazły się artykuły przybliżające kwestie związane z oddziaływaniem kryzysu na ramy finansowe Unii, wymiarem wschodnim Europejskiej Polityki Sąsiedztwa oraz zachodzącymi zmianami systemu politycznego.

Niezwykle istotny jest także wpływ kryzysu na aktywność Unii Europejskiej na arenie międzynarodowej, czemu poświęcony został artykuł przygotowany przez Pawła Olszewskiego i Adriana Chojana (Wpływ kryzysu gospodarczego na aktywność międzynarodowa Unii Euro- 
pejskiej). Autorzy przyjrzeli się w nim wewnętrznej i zewnętrznej sytuacji UE z perspektywy skutków kryzysu gospodarczego.

Na uwagę zasługuje również tekst zatytułowany Re-konfiguracja czy re-konstrukcja? Kryzysowe zmiany sensu systemu politycznego Unii Europejskiej. Krzysztof Szczerski zwraca w nim uwagę, że system polityczny Unii Europejskiej posiada zdolności adaptacyjne do zmiennych warunków. W tym kontekście Autor spogląda na działania UE podejmowane na rzecz przezwyciężenia kryzysu oceniając, że przekształcają one niekorzystnie system polityczny. Doprowadziło to do zmiany zasady, zgodnie z którą państwa-członkowie UE połączone są wspólnymi: budżetem, prawami, instytucjami oraz rynkiem. Zły kierunek następujących zmian związany jest z zastosowaniem nadzwyczajnych środków przeciwdziałających kryzysowi. Rekonstrukcja widoczna jest zwłaszcza na płaszczyźnie instytucjonalnej. Model instytucjonalny funkcjonujący na podstawie Traktatu z Lizbony został zachwiany przez układy instytucjonalne, na przykład Grupę Czterech skupiającą Szefów Komisji Europejskiej, Rady Europejskiej, Europejskiego Banku Centralnego oraz EuroGrupy. Ponadto opisuje trzy grupy procesów, których jesteśmy świadkami w Unii Europejskiej. Po pierwsze, innego znaczenia nabrało określenie „prędkość integracji” przesuwając się z wymiaru linearnego na przestrzenny, przy czym prędkość tą należy tu rozumieć jako zajmowanie miejsca w hierarchii. Po drugie, proces rekonstrukcji systemu europejskiego. Po trzecie, narodziny paneuropejskiej koncepcji demokracji określanej jako „plaster legitymizacyjny”. Każdy z wymienionych procesów niszczy podstawy, na których opiera się Unia Europejska. Autor przekłada to także na sytuację Polski.

Ostatnim artykułem w pracy jest tekst Wojciecha Gizickiego pod tytułem Wplyw kryzysu na region Europy Środkowej $i$ wspótpracę wyszehradzkq. Przyjrzano się w nim wpływowi kryzysu na współpracę podejmowaną w z państwami wyszehradzkimi. Autor zwrócił uwagę zarówno na negatywne oddziaływanie kryzysu, jak i na działania podejmowane w celu pokonania jego skutków. Przeanalizował stosunek państw V-4 do kryzysu (Polski i Słowacji oraz Czech i Węgier).

Pozycję zamykają Podsumowanie Tomasza Grzegorza Grosse (Cztery obszary analizy kryzysu w ekonomii politycznej) oraz Posłowie Jadwigi Staniszkis (Strategie w obliczu kryzysu (propozycje do dalszych badań)).

Publikacja w klarowny sposób prezentuje oddziaływanie kryzysu na wybrane elementy polityki unijnej. Napisana jest przejrzyście i nie sprawia czytelnikowi większych trudności w jej zrozumieniu. Niewątpliwym atutem książki jest to, że Autorzy przy omawianiu poszczególnych kwestii odnoszą je do przykładów państw europejskich. W publikacji ograniczono się do najistotniejszych, zdaniem Autorów, zagadnień związanych z badaną kwestią.

Zjawisku kryzysu poświęcono wiele miejsca w dostępnej literaturze. Recenzowana pozycja skupia się na ujęciu tego zagadnienia w wymiarze ekonomiczno-politologicznym. Należy zatem stwierdzić, że książka ta jest ważna z punktu widzenia aktualności badanego zagadnienia. Ponad dwustustronicowa publikacja wnosi wiele do podejmowanej problematyki, uzupełniając znakomicie istniejącą literaturę.

Należy stwierdzić, że publikacja ta jest ważna z punktu widzenia aktualności badanego zagadnienia. Przygotowana pozycja dotyczy niezwykle aktualnej problematyki. Stanowi ciekawe ujęcie skutków kryzysu w obrębie strefy euro i jego wpływu na funkcjonowanie Unii Europejskiej pod różnymi względami. Kryzys analizowano w niej z punktu widzenia politologicznego i ekonomicznego, opierając się na badaniu czterech następujących elementów: szans na rozwój systemu wspólnej waluty, sprawności w zarządzaniu, cechy strukturalne systemu oraz jego legitymizację polityczną. Na końcu książki znajduje się obszerna bibliografia. Przy powstawaniu pracy wykorzystano bogatą literaturę polską oraz zagraniczną. Oparto się o liczne dokumenty, opracowania, artykuły prasowe i materiały dostępne na stronach internetowych.

ANNA WESOŁOWSKA 